\title{
Prevalence of Vitamin D Deficiency and its Awareness and Knowledge Among Parents
}

\section{Pawana Kayastha, Robin Kumar Chaudhary and Subash Basnet}

Department of Paediatrics, Kathmandu Medical College and Teaching Hospital, Sinamangal, Kathmandu, Nepal

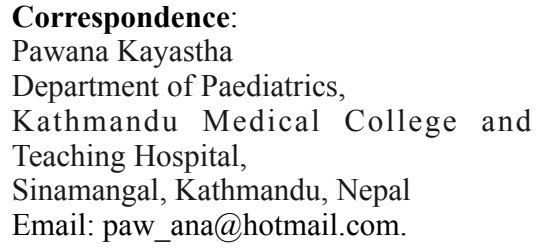

DOI: $10.3126 /$ jnps.v41i2.30657

Submitted on: $2020-08-16$

Accepted on: 2021-06-29

Acknowledgements: To all the parents and OPD staffs for support during research.

Funding: NEPAS Young Researcher Grant received as a fund in year 2076

Conflict of Interest: None declared

Permission from IRB: Yes

To cite this article: Kayastha $P$, Chaudhary RK, Basnet S. Prevalence of Vitamin D Deficiency and its Awareness and Knowledge Among Parents. J Nepal Paediatr Soc. 2021;41(2):226-32.

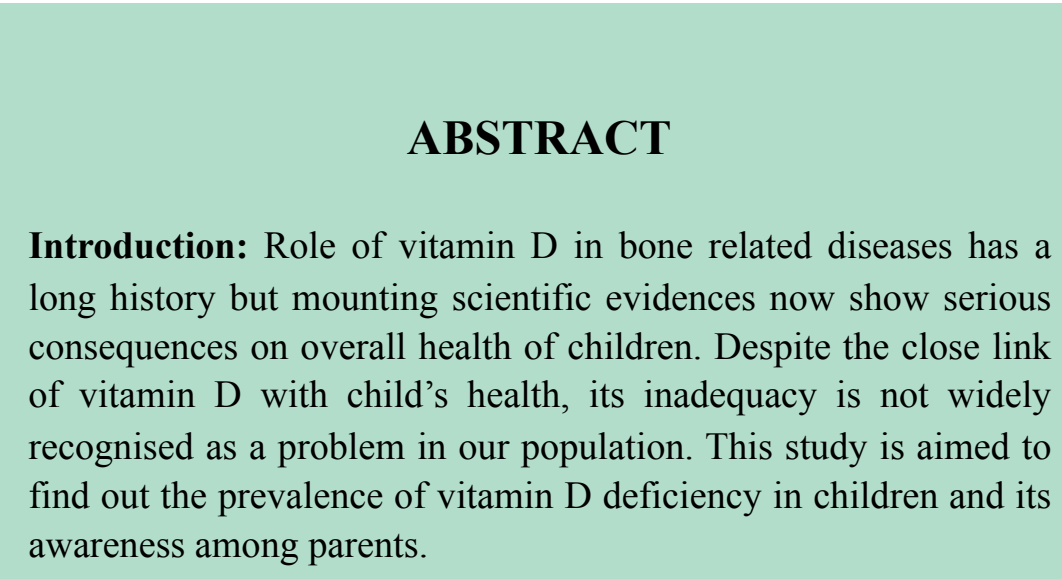

Methods: It is a prospective- cross-sectional study conducted in paediatric outpatient department of Kathmandu Medical College and Hospital from January to May 2020. Children of one to 15 years were included and 295 samples were taken. A pre-designed questionnaire was given to all participants. Vitamin $\mathrm{D}_{3}$ levels were tested with Chemiluminiscence Immuno Assay (CLIA) technique. The status of vitamin $\mathrm{D}$ was defined as deficient if vitamin $\mathrm{D}_{3}$ level less than $50 \mathrm{nmol} / \mathrm{l}$.

Results: Vitamin D deficiency were observed in $76.9 \%$ and among which $21 \%, 44.7 \%$ and $11.2 \%$ were mild, moderate and severe vitamin D deficiency respectively. Vitamin D level was observed significantly higher in males, younger children, those with presence of knowledge of vitamin $\mathrm{D}$ and those with adequate sun exposure. On the other hand factors like skin colour, time of exposure and exposed body parts to sun did not influence vitamin D level.

Conclusions: This study shows high prevalence of vitamin D deficiency among children but awareness among parents regarding vitamin $\mathrm{D}$ and its deficiency was low.

Key words: Awareness; Children; Sun exposure; Symptoms; Vitamin D

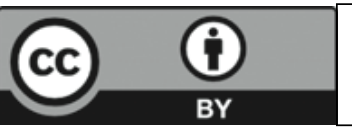

This work is licensed under creative common attribution 3.0 license 


\section{INTRODUCTION}

It is well-established that prolonged and severe vitamin D deficiency leads to rickets in children. However, rickets can be considered just the tip of iceberg. In addition to its negative impact on bone mineral density status, vitamin D deficiency also contributes to other chronic diseases, such as cardiovascular diseases, hypertension, diabetes and cancer. Its deficiency also increases the incidence of schizophrenia, depression and some inflammatory and autoimmune diseases. About one billion people worldwide are estimated to be suffering from vitamin D insufficiency. Vitamin D deficiency is an internationally recognised health problem and it is difficult to predict the magnitude of vitamin D deficiency amongst Nepalese children as no such data is available. However, few studies done in different areas of Nepal like Chitwan show the prevalence of $74.1 \%$ in children, in rural Nepal $91.1 \%$ and in Lalitpur $78.2 \%$ in young adults. ${ }^{-6}$ vitamin D is also called as "sunshine vitamin" as its main source is sunlight $(90 \%)$. The aim of this study was to find out Vitamin D deficiency status in children and to assess parent's awareness regarding vitamin $\mathrm{D}$, which could help to guide interventions in achieving the status of an adequate level of vitamin D amongst the Nepalese children.

\section{METHODS}

This is a prospective, cross-sectional study conducted in Paediatric Outpatient Department of Kathmandu Medical College, Sinamangal, Kathmandu, Nepal from January to May 2020. Children of age one year to 15 years and their parents were included in this study by simple random sampling method. Parents of children less than one year of age, medical personnel and those who refused to give consent were excluded from the study. A total of 295 samples were randomly selected from outpatient department. From previous published data, $74.1 \%$ was taken as prevalence rate and was calculated with absolute error of $5 \%$ and at type 1 error of $5 \%$ using formula sample size $=Z_{1}$ $\alpha / 2^{2} p(1-p) \div d^{2}$. A written informed consent was obtained from parents. All participants were provided with a pre-designed questionnaire. It included socio - demographic data, polar questions (yes or no type questions) and multiple choice questions to get information from parents regarding knowledge about sources of vitamin D and its deficiency. Approval from Institutional research committee was taken. The blood samples of children were sent to laboratory and vitamin $\mathrm{D}_{3}$ level was measured with Chemiluminiscence Immuno Assay (CLIA) technique. On the basis of recommendation of US Institute of medicine we took cut off value of $\geq 50 \mathrm{nmol} / 1$ for sufficient vitamin $\mathrm{D}_{3}$ level and further divided it into mild (25.1 - $49.9 \mathrm{nmol} / \mathrm{l})$, moderate $(12.6$ - $25 \mathrm{nmol} / \mathrm{l})$ and severe deficient $(0-12.5 \mathrm{nmol} / \mathrm{l})$.

\section{RESULTS}

A total of 295 cases included in this study, out of which $76.9 \%$ (i.e. 227 cases) had vitamin D deficiency and only $23.1 \%$ (i.e.68 cases) had sufficient vitamin $\mathrm{D}_{3}$ level (Figure 1).

The vitamin D level ranged from 6.2 to $105 \mathrm{nmol} / 1$ and mean level was $29.86 \pm 17.99$. Table 1 show vitamin D status of study population which has been categorised as sufficient, mild, moderate and severe deficiency.

Age of children included in this study ranged from one to 15 years and mean age were $8.48 \pm 4.58$ years. The mean age of deficient cases were $9.96 \pm$ 3.946 years and mean age of sufficient cases were $3.69 \pm 2.942$ years. Prevalence of vitamin D deficiency was encountered more in older children aged more than five years than preschool children. The association of age with vitamin $\mathrm{D}$ level was strongly significant with $\mathrm{p}$ - value of 0.000 (Figure 2).

There were $143(48.5 \%)$ male and 152 female $(51.5 \%)$ children enrolled in this study. The prevalence of vitamin D deficiency was seen more in female $57.3 \%$ (130) than male $42.7 \%$ (97) which was statistically significant with $\mathrm{p}$ - value of 0.000 (figure 3).

However, there were no statistically significant association observed between vitamin $\mathrm{D}_{3}$ level with children's skin colour and weight for age ( $p$ - value of 0.077 and 0.030 respectively).

Few parents who participated in the study declared that the main source of vitamin $\mathrm{D}$ was sunlight 


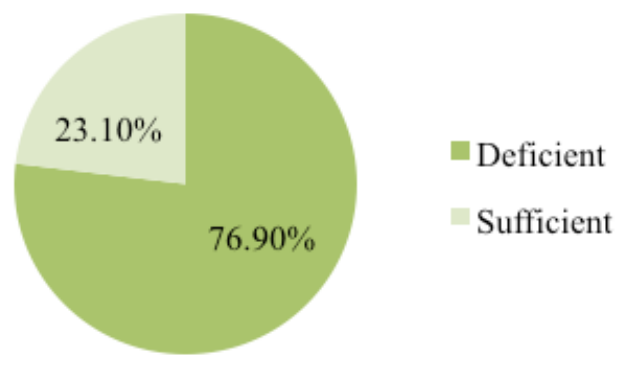

Figure 1. Prevalence of vitamin D deficiency in children

(31.9\%) but almost half of the parents did not know about any dietary sources of vitamin D (Table 2). Most frequently mentioned dietary sources were dairy products/milk (12.2\%) and mistaken response was dominated by fruits (10.5\%) and vegetables $(10.2 \%)$.

$82 \%$ of parents were unaware about need of vitamin $\mathrm{D}$ for calcium absorption and $52.9 \%$ aware of vitamin $\mathrm{D}$ in relation to growth whereas $56.3 \%$ of them mentioned absence of vitamin $\mathrm{D}$ in breastmilk. Among all, $66.8 \%$ of parents did not know about symptoms of vitamin $\mathrm{D}$ deficiency.

Most frequently mentioned symptoms were related to bone symptoms like bow leg, bone pain, delayed walking and bone fracture (Table 2). Most of the participants marked educational subject and least number marked public awareness and social media

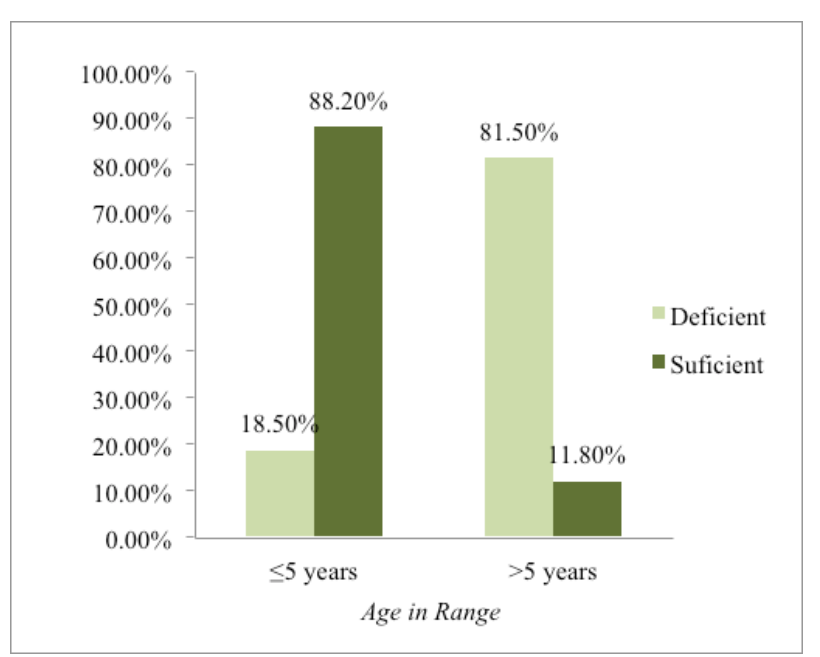

Figure 2. Prevalence of vitamin D deficiency in relation to age
Table 1. Vitamin D status of study

\begin{tabular}{|lrr|} 
Category & $\begin{array}{c}\text { Vitamin } \mathbf{D}_{\mathbf{3}} \\
\text { level (nmol/I) }\end{array}$ & \multicolumn{1}{c|}{$\begin{array}{c}\text { Prevalence } \\
\mathbf{( \% )}\end{array}$} \\
\hline Sufficient & $\geq 50$ & $68(23.1 \%)$ \\
Mild deficiency & $25.1-49.9$ & $62(21 \%)$ \\
$\begin{array}{l}\text { Moderate } \\
\text { deficiency }\end{array}$ & $12.6-25$ & $132(44.7 \%)$ \\
Severe deficiency & $0-12.5$ & $33(11.2 \%)$
\end{tabular}

as their source of knowledge of vitamin D. There were strong association of vitamin D level with duration of sun exposure and exposure of body parts. Vitamin D level was found to be higher in children with parents having knowledge about vitamin D. Table 3 shows the association between level of vitamin $\mathrm{D}$ with knowledge of parents and habit of sun exposure.

\section{DISCUSSION}

In this study, we observed high prevalence $(76.9 \%)$ of vitamin D deficiency in children, the result is similar to that recorded by Regmi et al. and Shrestha et al. where $74.1 \%$ and $78.2 \%$ were reported respectively. ${ }^{4,5} \mathrm{~A}$ few other studies that have investigated vitamin $\mathrm{D}$ status in different groups of population of Nepal were $73.68 \%$ in adults of western region as well as Kathmandu valley and $59.8 \%$ in lactating mothers of Bhaktapur. ${ }^{8}$ Most of the other Asian countries like India (84-100\%), Saudi Arabia (98.1\%), Malaysia (35.3\%), Korea (59.1\%) also had high prevalence of Vitamin D deficiency. ${ }^{7-9}$ The Asian diet with its paucity of foods containing vitamin D and high phytate content may be the cause of rise in vitamin

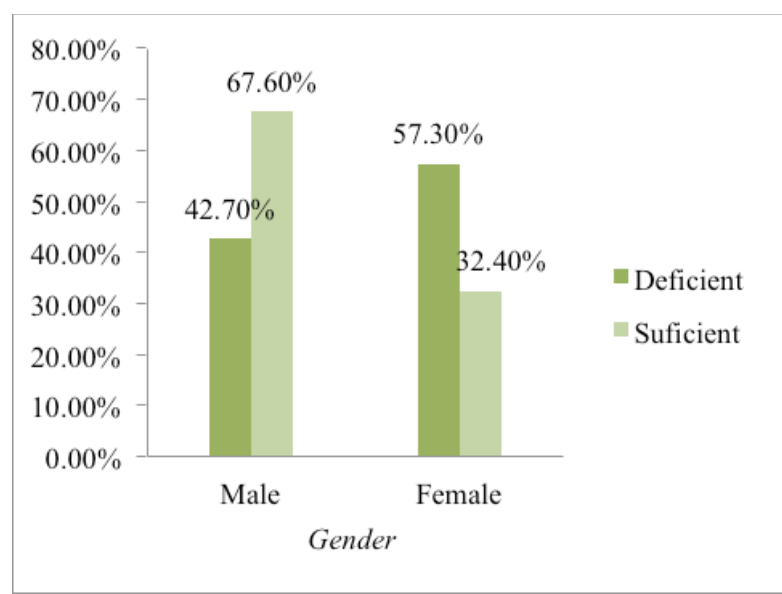

Figure 3. Prevalence of vitamin D deficiency 
Table 2. Variables describing awareness of Vitamin $\mathrm{D}$, its sources and deficiency among parents

\begin{tabular}{|c|c|c|}
\hline Variables & & Number (\%) \\
\hline \multirow{4}{*}{$\begin{array}{l}\text { Sources of } \\
\text { vitamin D }\end{array}$} & Sunlight & $94(31.9 \%)$ \\
\hline & Dietary supplements & $28(9.5 \%)$ \\
\hline & Healthy foods & $74(25.1 \%)$ \\
\hline & None & $99(33.5 \%)$ \\
\hline \multirow{2}{*}{$\begin{array}{l}\text { Vitamin D in } \\
\text { breast milk }\end{array}$} & Yes & $129(43.7 \%)$ \\
\hline & No & $166(56.3 \%)$ \\
\hline \multirow{2}{*}{$\begin{array}{l}\text { Vitamin D for } \\
\text { Calcium } \\
\text { absorption }\end{array}$} & Yes & $53(18 \%)$ \\
\hline & No & $242(82 \%)$ \\
\hline \multirow{6}{*}{$\begin{array}{l}\text { Symptoms of } \\
\text { vitamin D } \\
\text { deficiency }\end{array}$} & Bow leg & $30(10.2 \%)$ \\
\hline & Delayed walking & $16(5.4 \%)$ \\
\hline & Bone fracture & $21(7.1 \%)$ \\
\hline & Bone pain & $30(10.21 \%)$ \\
\hline & Tooth ache & $1(3 \%)$ \\
\hline & I don't know & $197(66.8 \%)$ \\
\hline \multirow{10}{*}{$\begin{array}{l}\text { Dietary sources } \\
\text { of vitamin } D\end{array}$} & Fruits & $31(10.5 \%)$ \\
\hline & Vegetables & $30(10.2 \%)$ \\
\hline & Fatty fish & $13(4.4 \%)$ \\
\hline & Milk/dairy products & $36(12.2 \%)$ \\
\hline & Cod liver oil & $8(2.7 \%)$ \\
\hline & Eggs & $15(5.1 \%)$ \\
\hline & Nuts & $5(1.7 \%)$ \\
\hline & Selected cereals & $8(2.7 \%)$ \\
\hline & Meat & $5(1.7 \%)$ \\
\hline & I don't know & $144(48.8 \%)$ \\
\hline \multirow{4}{*}{$\begin{array}{l}\text { Reason for } \\
\text { inadequate } \\
\text { exposure to sun }\end{array}$} & $\begin{array}{l}\text { Not enough } \\
\text { information }\end{array}$ & $176(59.7 \%)$ \\
\hline & $\begin{array}{l}\text { Fear of skin cancer/ } \\
\text { burn }\end{array}$ & $11(3.7 \%)$ \\
\hline & Weather issue & $14(4.7 \%)$ \\
\hline & Physical issues & $94(31.9 \%)$ \\
\hline \multirow{6}{*}{$\begin{array}{l}\text { Sources of } \\
\text { knowledge } \\
\text { about vitamin D } \\
\text { deficiency }\end{array}$} & Social media & $9(3.1 \%)$ \\
\hline & $\begin{array}{l}\text { Public awareness } \\
\text { campaign }\end{array}$ & $7(2.4 \%)$ \\
\hline & Doctors/nurses & $21(7.1 \%)$ \\
\hline & Relatives / friends & $20(6.8 \%)$ \\
\hline & Educational subjects & $35(11.9 \%)$ \\
\hline & None & $203(68.8 \%)$ \\
\hline
\end{tabular}

Table 3. Association of vitamin D3 status with variable of knowledge of Vitamin D and habit of sun exposure

\begin{tabular}{|c|c|c|c|c|}
\hline \multirow[t]{2}{*}{ variables } & \multicolumn{2}{|c|}{ Vitamin D3 } & \multirow[t]{2}{*}{ P value } & \multirow{2}{*}{$\begin{array}{c}\text { Odd } \\
\text { ratio; } \\
95 \% \\
\text { Confiden } \\
\text { ce } \\
\text { Interval }\end{array}$} \\
\hline & Deficient & Sufficient & & \\
\hline \multicolumn{5}{|l|}{$\begin{array}{l}\text { Knowledge } \\
\text { of vitamin } \\
\text { D }\end{array}$} \\
\hline No & $\begin{array}{r}177 \\
(78 \%)\end{array}$ & $\begin{array}{r}26 \\
(38.2 \%)\end{array}$ & 0.000 & $\begin{array}{l}3.564 ; \\
2.33-\end{array}$ \\
\hline Yes & $\begin{array}{r}50 \\
(22 \%)\end{array}$ & $\begin{array}{r}42 \\
(61.8 \%)\end{array}$ & & 5.43 \\
\hline \multicolumn{5}{|l|}{$\begin{array}{l}\text { Time of } \\
\text { exposure } \\
\text { to Sun }\end{array}$} \\
\hline Morning & $\begin{array}{r}162 \\
(71.4 \%)\end{array}$ & $\begin{array}{r}58 \\
(85.3 \%)\end{array}$ & 0.013 & $\begin{array}{r}1.9 \\
1.066-3.6\end{array}$ \\
\hline Evening & $\begin{array}{r}65 \\
(28.6 \%)\end{array}$ & $\begin{array}{r}10 \\
(14.7 \%)\end{array}$ & & 68 \\
\hline \multicolumn{5}{|l|}{$\begin{array}{l}\text { Duration } \\
\text { of sun } \\
\text { exposure }\end{array}$} \\
\hline $\begin{array}{l}<30 \\
\text { Minutes }\end{array}$ & $\begin{array}{r}137 \\
(60.4 \%)\end{array}$ & $\begin{array}{r}12 \\
(17.6 \%)\end{array}$ & 0.000 & $\begin{array}{r}7.1204 \\
3.607-13 \\
991\end{array}$ \\
\hline $\begin{array}{l}>30 \\
\text { Minutes }\end{array}$ & $\begin{array}{r}90 \\
(39.6 \%)\end{array}$ & $\begin{array}{r}56 \\
(82.4 \%)\end{array}$ & & \\
\hline $\begin{array}{l}\text { Exposed } \\
\text { body parts }\end{array}$ & & & & \\
\hline $\begin{array}{l}\text { Hand / } \\
\text { Face }\end{array}$ & $\begin{array}{r}158 \\
(69.6 \%)\end{array}$ & $\begin{array}{r}14 \\
(20.6 \%)\end{array}$ & 0.000 & $\begin{array}{r}8.832 \\
4.6-16.95\end{array}$ \\
\hline Others & $\begin{array}{r}69 \\
(30.4 \%)\end{array}$ & $\begin{array}{r}54 \\
(79.4 \%)\end{array}$ & & 8 \\
\hline
\end{tabular}

$\mathrm{D}$ deficiency in this region. On the other hand, the prevalence in Sweden (3\%), US (9\%), Netherland $(23.6 \%)$ were lower but in Turkey it was seen in $40 \%$ however their cutoff values varied from that of our cutoff values. ${ }^{-10}$ The controversy over cutoff value of vitamin D status as well as wide difference in latitude, altitude, cloud cover and air pollution in different geographical variations may also have contributed for wide variation in the data. Among total deficient cases of our study we found least number $(11.2 \%)$ of cases in severe deficiency category. The other two studies done by Avagyan et al. and Voortman et al. reported similar data from their research. 6,17 The mean vitamin D level recorded in this study was $29.86 \pm 17.99 \mathrm{nmol} / \mathrm{l}$, 
but much lower mean value $(19.93 \pm 6.6 \mathrm{nmol} / \mathrm{l})$ was observed in an Indian study done in 2017. In our study, a higher prevalence was observed in school going children however, no association of vitamin D level with age was seen in Roh et al. and Anitha et al. study. ${ }^{14,19}$ There was no difference in mean age of deficient $(10.2 \pm 4.2)$ and sufficient $(10.09 \pm 4.09)$ cases in Alshamsan et al. study but in our study mean age of deficient cases were 9.96 \pm 3.94 years and mean age of sufficient was $3.69 \pm$ 2.94 years.

This study observed vitamin D deficiency higher in girl child. Multiple other studies reported higher prevalence of vitamin D deficiency in females. ${ }^{9-11}$ On contrary there are also studies which do not show association of gender with vitamin D level. ${ }^{4,6,10,14}$ Multiple factors like use of sunscreen, shades during outdoor activities and more hours of screen time may have affected vitamin D level in these groups of children.

In the study done by Anitha et al., skin colour was not found to be associated with vitamin D status which was comparable with our study. ${ }^{19}$ But in AlShaikh et al.'s study, children with dark skin had lower concentrations of vitamin D. ${ }^{22}$ A study done in Australia and Saudi showed low level of knowledge of Vitamin D among participant. ${ }^{10,22}$ In contrast to our study, in Jeddan population majority had heard about vitamin D. In our study, reasons for inadequate exposure to sun were mostly not enough information $(59.7 \%)$ and physical issues (31.9\%) whereas in Australian population it was for fear of skin cancer, sun burn and extreme weather condition. ${ }^{24}$ In Jeddan population $65.5 \%$ recognised work or weather issues as major cause of inadequate exposure to sun. ${ }^{25}$

Similar to our study, a survey in Poland showed that the most frequently mentioned sources of vitamin $\mathrm{D}$ was dairy products and mistaken responses were dominated by fruits and vegetables.
But source of information about vitamin $\mathrm{D}$ varied as compared to our study. ${ }^{24,25}$

In Saudi, only $50 \%$ of patients were aware of heath implication of vitamin D. ${ }^{20} \quad 66.8 \%$ of our participants also was unaware of any symptoms of vitamin D deficiency. In Zadka et al.'s study the respondents mostly declared vitamin D property as structure of bones and teeth $(66 \%)$ and the report corresponds to our result as our respondents also only mentioned bone symptoms for vitamin D deficiency. ${ }^{26}$ Knowledge of vitamin D, duration of sun exposure and exposed body parts were only found to be associated with vitamin D status in our study which is in congruence the study done in Pune by Mandlik et al. ${ }^{23}$ Although our study is a novel study in our country, being hospital based, our results may not represent the status of the entire population. Another important drawback of our research is that we have not correlated vitamin $\mathrm{D}$ status with other laboratory parameters like serum calcium, phosphorus and parathyroid hormones which could have important significance. However, we expect that further, larger, prospective studies in the future would be able to shed more light upon this area.

\section{CONCLUSIONS}

High prevalence of vitamin D deficiency and its lack of knowledge in parents were identified in our study. Fortification of food and vitamin D supplementation along with spreading awareness to parents by conducting large scale information campaigns should be the key elements in counteracting the widespread vitamin D deficiency in children of Nepal.

\section{REFERENCES}

1. Cashman KD. Vitamin D in childhood and adolescence. Postgrad Med J. 2007;83:230-5. DOI: 10.1136/pgmj. 2006.052787

2. Larijani B, Nezhad AH, Feizabad E, Maghbooli Z, Adibi H, Ramezani M, et al. Vitamin D deficiency, bone turnover markers and causative factors among adolescents: a cross-sectional study. J Diabetes Metab Disord. 2016; 15:46. DOI: $10.1186 / \mathrm{s} 40200-016-0266-2$ 
3. Zhao X, Xiao J, Liao X, Cai L, Xu F, Chen D, et al. Vitamin D Status among Young Children Aged 1-3 Years: A Cross-Sectional Study in Wuxi, China. PLoSONE. 2015;10(10):e0141595. DOI:10.1371/journal.pone.0141595

4. Regmi S, Regmi AP, Adhikari S, Shakya D. Prevalence of vitamin d deficiency/ insufficiency among children and adolescents. JCMC. 2017;7(19)1-5.

5. Shrestha S, Shrestha L, Jha DK. Vitamin D status among individuals attended in Health Home Care centre, Lalitpur, Nepal. Nepal Med Coll J. 2012;14(2):84-7.

6. Avagyan D, Neupane SP, Gundersen TE, Madar AA. Vitamin D status in pre-school children in rural Nepal. Public Health Nutr. 2015;11:1-7. DOI:10.1017/S136898001500083X

7. Almehmadi BM, Fallata EM, Alqahtani SZ, Al-Agha AE. The Effects of Physical Activity and Sun Exposure on Vitamin D Status among Children from Jeddah, Saudi Arabia. J Pediatr Care. 2016;2(2):1-5. DOI: 10.21767/2471-805X.100009

8. Institute of Medicine. Dietary Reference Intakes for Calcium and vitamin D; The National Academies: Washington, DC, USA, 2011. DOI: $10.17226 / 13050$

9. Bhatta MP, Pandey BR, Gurung KM, Nakarmi R, Gurung K, Gurung LB, et al. Prevalence of Vitamin D deficiency among adult population of Western Region of Nepal. IJMBS. 2016;1(2):7-12

10. Rai CK, Shrestha B, Sapkota J, Das JK. Prevalence of Vitamin D Deficiency among Adult Patients in a Tertiary Care Hospital. J Nepal Med Assoc. 2019;57(218):226-8. DOI: https://doi.org/10.31729/jnma.4534

11. Haugen J, Ulak M, Chandyo RK, Henjum S, Thorne-Lyman AL, Ueland PM, et al. Strand Low Prevalence of Vitamin D Insufficiency among Nepalese Infants Despite High Prevalence of Vitamin D Insufficiency among Their Mothers. Nutrients. 2016;8(12):825-9. DOI: 10.3390/nu8120825

12. Kamboj P, Dwivedi S, GS Toteja1. Prevalence of hypovitaminosis D in India and way forward. Indian J Med Res. 2018;148(5):548-56. DOI: 10.4103/ijmr.IJMR_1807_18

13. Khor GL, Chee WS, Shariff ZM, Poh BK, Arumugam M, Rahman JA, et al. High prevalence of vitamin D insufficiency and its association with BMI-for-age among primary school children in Kuala Lumpur, Malaysia. BMC Public Health. 2011;11:95. DOI: 10.1186/1471-2458-11-95

14. Roh YE, Kim BR, Choi WB, Kim YM, Cho MJ, Kim HY, et al. Vitamin D deficiency in children aged 6 to 12 years: single center's experience in Busan. Ann Pediatr Endocrinol Metab. 2016;21(3):149-54. DOI: 10.6065/apem. 2016.21.3.149

15. Anderssona B, Swolin-Eideb D, Magnussonc P, Wikland KA. Vitamin D status in children over three decades - Do children get enough vitamin D? Bone Reports. 2016;5(1)150-2. DOI: https://doi.org/10.1016/j.bonr.2016.03.002

16. Melamed ML, Kumar J. Low levels of 25-hydroxyvitamin D in the paediatric populations: prevalence and clinical outcomes. Ped Health. 2010;4(1):89-97. DOI:10.2217/phe.09.72

17. Voortman T, van den Hooven EH, Heijboer AC, Hofman A, Jaddoe VW, Franco OH. Vitamin D deficiency in school-age children is associated with sociodemographic and lifestyle factors. J Nutr. 2015;145(4):791-8. DOI: $10.3945 /$ jn. 114.208280

18. Andıran N, Çelik N, Akça H, Doğan G. Vitamin D Deficiency in Children and Adolescents. J Clin Res Pediatr En docrinol. 2012;4(1):25-9. DOI : 10.4274/jcrpe.574

19. Anitha A, Poovathinal SA, Viswambharan V, Thanseem I, Vasu MM, Ranjitha M. Cross-sectional study reveals a high prevalence of vitamin D deficiency among healthy school children in central Kerala, India. Int J Contemp Pediatr. 2019;6(2):867-71. DOI: http://dx.doi.org/10.18203/2349-3291.ijcp20190745.

20. Alshamsan FM, Bin-Abbas. Knowledge, awareness, attitudes and sources of vitamin D deficiency and sufficiency in Saudi children. Med J. 2016;37(5):579-83. DOI:10.15537/smj.2016.5.14951

21. Marwaha RK, Tandon N, Reddy DR, Aggarwal R, Singh R, Sawhney RC, et al. Vitamin D and bone mineral density status of healthy schoolchildren in northern India. Am J Clin Nutr. 2005;82(2):477-82. DOI:10.1093/ajcn. 82.2.477.

22. Al Shaikh AM, Abaalkhail B, Soliman A, Kaddam I, Aseri K, Al Saleh Y, et al. Prevalence of Vitamin D Deficiency and Calcium Homeostasis in Saudi Children. J Clin Res Pediatr Endocrinol. 2016;8(4):461-7. DOI:10.4274/jcrpe. 3301 
23. Mandlik R, Kajale N, Ekbote V, Patwardhan V, Khadilkar V, Chiplonkar S, et al. Determinants of Vitamin D status in Indian school-children. Indian J Endocr Metab. 2018;22:244-8. DOI: 10.4103/2230-8210.232385

24. Bonevski B, Bryant J, Lambert S, Brozek I, Rock V. The ABC of vitamin D: a qualitative study of the knowledge and attitudes regarding vitamin D deficiency amongst selected population groups. Nutrients. 2013;5(3):915-27. DOI:10.3390/nu5030915

25. Al-Agha AE, Alorabi SH, Noor Saeed SMW, Shalabi NMJ. Comm Awareness of Vitamin D and its Deficiency in Jeddah Population, Saudi Arabia. Pub Health Nurs. 2016;2:2. DOI:10.4172/2471-9846.1000120

26. Zadka K, Pałkowska-Goździk E, Rosołowska-Huszcz D. The State of Knowledge about Nutrition Sources of Vitamin D, Its Role in the Human Body, and Necessity of Supplementation among Parents in Central Poland. Int J Environ Res Public Health. 2018;15(7):1489. DOI:10.3390/ijerph15071489 